COMMENT

DOI: 10.1057/s41599-018-0169-6

\title{
The Russian Orthodox Church, the Kremlin, and religious (il)liberalism in Russia
}

Jeremy W. Lamoreaux ${ }^{1} \&$ Lincoln Flake ${ }^{2}$

\section{ABSTRACT}

The apparent 'symphonia' of church-state cooperation in Russia is a matter of debate and concern in the West. By some accounts the war in Ukraine kicked that collusion into another gear entirely, with the Russian Orthodox Church now a fully assimilated part of the Kremlin's domestic and foreign policy machine. We argue that, though such claims may prove hyperbolic, the rise in political authoritarianism in Russia and its neighbourhood is being matched by significant restrictions in Russia's religious playfield, and that both the Kremlin and the Russian Orthodox Church benefit from the policies and practices of the other. Consequently, now is not a good time to be a member of a non-traditional church or of a so-called foreign sect in Russia. More disconcerting, a continuation of these trends may portend further crackdowns not just on religious freedoms, but across the spectrum of civil liberties in Russia.

\footnotetext{
${ }^{1}$ Brigham Young University-Idaho, Rexburg, ID 83460, USA. ${ }^{2}$ National Intelligence University, Bethesda, MD, USA. Correspondence and requests for materials should be addressed to J.W.L. (email: lamoreauxj@byui.edu)
} 


\section{0s: Orthodoxy re-established}

eligious pluralism was always going to be a tenuous proposition in post-Soviet Russia. The church-state models of the Tsarist and Communist eras were not particularly encouraging antecedents. Furthermore, pluralism of any kind does not have a rich history in Russia (Grigoriadis, 2016). PreSoviet experiments in various social domains were infrequent, short-lived and often inconsequential. Thus, while Eastern European nations were at least able to appeal to limited precommunist experiences in a vibrant civil society, Russia had no such institutional memory upon which to draw after 1991. This partially explains the brief, frenzied and ultimately unsuccessful flirt with open institutions in the 1990s. Even so, religious pluralism fared surprisingly well when compared with the failure of other social institutions attempting to transition to Western norms. Indeed, the diversity of religious groups including nontraditional and foreign denominations flourished during the turbulent years of Yeltsin's reign.

This was all to the chagrin of the Russian Orthodox Church which viewed (and still views) the simultaneous presence of disparate religious traditions within Russian society (especially those associated with the West) as a threat (White and Palkin, 2017). After all, there was precedence in the late tsarist era when church and state joined forces to combat protestant sectarianism (Polunov, 2012).

Nonetheless, the Russian Orthodox Church did have some success in re-establishing itself as the dominant religion in Russia, often through state supported legislation. Specifically, two changes illustrate the Church's renewed dominance on the religious playfield. First, starting early in the 1990s, the state began to return Church land seized by the state. This reinforced, in a geographical sense, the churches position as the dominant religious group in Russia. Second, according to Marsh and Koesel, the 1997 law on 'Freedom of Conscience and Religious Association' provided implicit leverage to the Church by limiting what other religious organisations could do. Furthermore, though the preamble mentions Christianity (generally), Islam, Judaism and Buddhism and traditional religions, it is perceived as specifically elevating Orthodoxy's standing in society (2016, p. 42). Thus, despite the changes ultimately proving more symbolic than substantial, with minority faiths operating relatively unfettered, the Russian Orthodox Church was again on the ascent.

\section{Authoritarianism and traditionalism}

Continuity with Russia's illiberal past returned with Vladimir Putin. Balzer (2003) labelled the early Putin years as a time of 'managed pluralism' in which diversity was allowed in political parties, the media, labour unions, civil society, business associations and other domains as long as activity remained within regime-imposed boundaries and quotas. Following a decade of disorder, the public was more than willing to go along. Unsurprisingly, this 'managed pluralism' quickly shifted toward the increased state control we see in many domains today, such as broadcast media (Lukyanova, 2015; Tolz, 2017) and foreign nonfor-profit organisations (Human Rights Watch 2018a). By 2004, McFaul declared that Putin had 'undermined every independent source of political power' (2004).

As regards religion, even in the early years of his tenure Putin saw the value in religious imaging and acted accordingly. As early as 2000, when 'spiritual renewal' was highlighted in the National Security Concept as well as other government policies, critics argue that Putin intended to cloak his regime in a type of Orthodox nationalism (Blitt, 2011, p. 457). And though this proved accurate, Putin's first two terms proceeded without a significant deterioration in religious rights or the diversity of civil society groups.

At the same time, the Russian Orthodox Church continued its ascendency as the predominant player on Russia's religious playfield. Specifically, policy changes in the first few years of Kirill's term as Patriarch, either building on existing policy or adding new protections for the Church, helped the ROC solidify its position and slowly edge out competing religious groups. Three changes illustrate this point.

1. A 2010 policy strengthened the Church's claim on lands seized during the Soviet era, and gave (then) current land owners two years to surrender former ROC lands to the Church. Previously, this had been a much more gradual process, and had happened at the will of the federal government. The new policy allowed the Church to actively claim those lands and refer to the government for enforcement (Kishkovsky, 2010).

2. A 2009 directive allowed religious education in public schools. This law, overturning a 1992 law that outlawed the practice, paved the way for an Orthodoxy module introduced in 2012. Even though this module is meant to be nonevangelizing, critics argue that the Church successfully uses this course not only to strengthen its own position in Russian society, but to propagate its ideal of a Russian national identity (which, perhaps not surprisingly, coincides well with that advocated by the Kremlin) (Köllner, 2016).

3. The third change built on the financial benefits the Church was already receiving, such as tax breaks, to include partial ownership of energy firms, and government subsidies on utilities. It is important here to note that this did not eliminate the Church's responsibility to pay taxes (which they do), but does ease their tax burden. (Solodovnik, 2014, p. 58-59)

\section{Unity, rift and reconciliation}

At the same time, the church seemed more willing to support the Kremlin's tendency toward authoritarianism. This was on display when the church supported the regime suppressing the 2011-2012 protests (Solodovnik, 2014, p. 74-75), backed the government's highly controversial ban on foreign adoptions, discredited the regime's political opponents, and during specific events such as the Pussy Riot episode (Tolstaya, 2014). Additionally, coordination on such initiatives as the soft-power Russkiy Mir project happened overtly in regularly meetings between the Church's Department of External Church Relations and Russia's Ministry of Foreign Affairs (Blitt, 2011, p. 383). Yet, despite all of this, non-Orthodox believers were merely anxious, not greatly injured by church-state collusion. Though Jehovah's Witnesses seemed to specifically draw the ire of state officials, most other religious groups operated largely unfettered by the state.

Circumstances changed in 2014 with the war in Ukraine. Where the ROC and the state seemed to be marching in lockstep prior to 2014, the Kremlin's annexation of Crimea, and support of separatists in the Donbas region, revealed significant rifts in policy perspectives. Patriarch Kirill was originally opposed to the annexation of Crimea and the media's practice of throwing church authority behind the LNR/DNR opposition forces (Ziegler, 2016, p. 561-562; Suslov, 2016, p. 140-141). He likely understood that such a course would undermine the church's efforts to gain greater influence in Ukraine vis-à-vis the Kyiv Patriarchate. The numbers bear this out. The Russian Orthodox Church, and the Ukrainian Orthodox Church-Moscow 
Patriarchate are both losing numbers in Ukraine (Kochan, 2016, p. 118)

However, Kirill's opposition was soon silenced (though never retracted), and implicit church support became a key component of Russia's all-of-government approach to foreign affairs, known broadly as 'hybrid warfare'. That concept consists of the integrated use of multiple political, military, technological, and societal tools deployed in a synchronised manner, and primarily by non-kinetic means, to achieve the Kremlin's aims (Conley et al., 2016). Apparent support of the Russian Orthodox Church was quickly operationalised as a non-military element in the Ukraine War (Simons, 2016; Leustean, 2017).

According to several authors, the Kremlin, the media and the Donbas separatists relied on nationalist propaganda which alleged Orthodox support to sell the war to the public and to occupied peoples. Specifically, much of the propaganda made a specific point of painting the West (toward whom the Ukrainian government was leaning) as corrupt, non-Orthodox and, therefore, non-Russian (Laruelle, 2016; Suslov, 2016).Propaganda was issued that stirred up minorities against Westernisation (Tolz, 2017)and attacked specific 'Western' practices such as abortion, same-sex marriage, and reproductive technologies (Agadjanian, 2017).

\section{Restructuring the playfield}

Just as church policy (even if unofficial) supported government policy, government policy also increasingly favoured the Church. By 2016, Russia's restructured religious playfield favoured the Russian Orthodox Church even more. The state did this legislatively. The 1997 religious law was amended in July 2015 to require all religious communities that do not have legal status to notify the authorities of their existence and activities. This was followed by an even more draconian and unambiguous move. The Federal Law 374-FZ drastically changed the face of religious activity in Russia. The law sponsored by a United Russia parliamentarian passed the Duma almost unanimously.

The 2016 law, also known as the 'Yarovaya Law', was an amendment to the original 2002 'Extremism' Law. In 2002, many believed that the state would use the ambiguous language of the 'Extremism' law to target non-desirable religious communities and individuals. While that fear was never fully validated, the Yarovaya Law has lived up to, and exceeded, its hype. The law significantly limits proselytising and restricts religious assembly from occurring any place but in officially recognised religious buildings. Even a prayer meeting in someone's flat is prohibited. The statutes were expertly crafted to only harm the activity of 'Low Churches' or non-traditional groups that rely on laity and evangelical principles for growth. A 'High Church', with its liturgical, ceremonial nature, like the Russian Orthodox Church, is largely unaffected, even if the law were to be fairly administered.

In contrast with previous legislation which was not actively enforced, Yarovaya Law has produced tangible results. The 2 years following passage of the law witnessed hundreds of cases (many arbitrary) against individuals and groups that violated authorities' broad interpretation of the law (Verkhovsky, 2018).

Nevertheless, until recently, prosecutions have been selective, driven primarily by the whims of local officials and thugs in concert with Orthodox priests rather than as a result of a federal campaign of oppression (Verkhovsky, 2016) In fact, some of the wind-down of religious activity is due to self-regulation rather than as a result of formal suppression (Groys, 2016). The example of the Mormons is illustrative. Since 1993, white-shirted, 19-yearold Mormon missionaries have been ubiquitous in most large Russian cities. Thousands joined the fold and congregations have multiplied with over 20,000 current members. Yet the Mormon Church strictly abides by all local laws. Regardless, the new rules have effectively ended proselyting efforts, resulting in lower missionary numbers, converts and activity. Furthermore, small group and home-based teaching is now forbidden. The fear, suspicion, and outright oppression that such groups now endure are eerily reminiscent of the Soviet era.

However, self-regulation is not the only source of religious disquiet, as outright suppression is also on the rise. For example, the Jehovah's Witnesses are, by-and-large, law abiding. They pay taxes, live a healthy lifestyle, and promote many social values championed by the Russian Orthodox Church and the Kremlin such as strong families and traditional social values. Yet, they also enshrine practices that are contradictory to Yarovaya law, such as proselytising through small group and home-based teaching. Perhaps more damning, they tend to relegate the law of the land to second place behind God's law. As a result, they are specifically targeted by state officials and, as of 2017, have been banned in Russia with draconian suppression and imprisonments accelerating in 2018 (Human Rights Watch, 2018b).

\section{Implications}

These two examples effectively highlight the real impact of the Yarovaya Law: the dual trends of formalised suppression and selfregulation within the non-traditional religious sphere. Both of these trends give the Kremlin and the Russian Orthodox Church space to restructure the religious marketplace with impunity. Perhaps most disconcerting is what this onslaught on religious minorities portends for civil society at large in Russia. Freedom of religion is usually a reliable barometer of the long-term trajectory of civil society. If this is the case, and we believe it is, developments in the religious space are a poor omen for broader human rights and civil society in Russia

Received: 19 April 2018 Accepted: 6 September 2018

Published online: 25 September 2018

\section{References}

Agadjanian A (2017) Tradition, morality and community: elaborating orthodox identity in Putin's Russia. Relig State Soc 45(1):39-60

Balzer H (2003) Managed pluralism: Vladimir Putin's emerging regime. Post-Sov Aff 19(3):189-227

Blitt RC (2011) Russia's 'Orthodox' foreign policy: the growing influence of the Russian Orthodox Church in shaping Russia's policies abroad. Univ Pa J Int Law 2 363-460

Conley HA, James M, Ruslan S, Martin V (2016) The Kremlin playbook: understanding Russian influence in Central and Eastern Europe. Rowman \& Littlefield, Lanham

Grigoriadis T (2016) Religious origins of democracy \& dictatorship. J Policy Model 38:785-809

Groys B (2016) Hurting the feelings of others. Social Res 83(1):211-215

Human Rights Watch (2018a) Russia: Government vs. Rights Groups: The Battle Chronicle. Human Rights Watch. https://www.hrw.org/russia-governmentagainst-rights-groups-battle-chronicle. Accessed 26 June 2018

Human Rights Watch (2018b) Russia: sweeping arrests of Jehovah's witnesses. Human Rights Watch. https://www.hrw.org/news/2018/06/28/russiasweeping-arrests-jehovahs-witnesses. Accessed 20 July 2018

Kishkovsky S (2010) Russia to return Church property. New York Times, 23 November

Kochan N (2016) Shaping Ukrainian identity: the Churches in the socio-political crisis. In: Krawchuk A, Bremer T (eds) Churches in the Ukrainina crisis, ch 5. Palgrave Macmillan, Switzerland, pp 105-122

Köllner T (2016) Patriotism, orthodox religion and education: empirical findings from contemporary Russia. Relig State Soc 44(4):366-386

Laruelle M (2016) The three colors of Novorossiya, or the Russian nationalist mythmaking of the Ukrainian crisis. Post Sov Aff 32(1):55-74

Leustean LN (2017) Eastern Orthodoxy, geopolitics and the 2016 'Holy and Great Synod of the Orthodox Church' Geopolitics 23:201-216 
Lukyanova GV (2015) Framing Russian orthodox Church: how Russian stateowned media covered the Church/religion. Rom J Journal Commun 10 (3):25-32

Marsh C, Koesel KJ (2016) Toward a strategy for engaging a resurgent Russia on democracy, human rights, and religious liberty. Rev Faith Int Aff 14(2):40

McFaul M (2004) State of Siege: Putin's strong hand is failing Russia. Carnegie Endowment for International Peace. https://carnegieendowment.org/2004/ 09/12/state-of-siege-putin-s-strong-hand-is-failing-russia-pub-15793. Accessed 20 July 2018

Polunov A (2012) The problem of religious freedom in late imperial Russia: the case of Russian Baptists. J Eurasia Stud 3:161-167

Simons G (2016) The Russian Orthodox Church: toward a new, global role? Cicero Foundation Great Debate Papers 16(6)

Solodovnik S (2014) Russia: the official Church chooses the state. Russ Social Sci Rev 55(6):55

Suslov M (2016) The Russian Orthodox Church and the crisis in Ukraine. In: Krawchuk A, Bremer T (eds) Churches in the Ukrainian crisis. Palgrave Macmillan: London

Tolstaya K (2014) Stained glasses and coloured lenses: The Pussy Riot case as a critical issue for multidisciplinary scholarly investigations. Relig Gend 4 (2): 100

Tolz V (2017) From a threatening 'Muslim Migrant' back to the conspiring 'West:' race, religion, and nationhood on Russian television during Putin's third presidency. Natl Pap 45(5):742-757

Verkhovsky A (2016) Freedom of conscience in Russia: restrictions and challenges in 2015. SOVA Center for Information and Analysis. http://www.sova-center. $\mathrm{ru} / \mathrm{en} /$ religion/publications/2016/04/d34317/. Accessed 7 Dec, 2016

Verkhovsky A (2018) Freedom of conscience in Russia: restrictions and challenges in 2017. SOVA. Center for Information and Analysis. https://www. sova-center.ru/en/religion/publications/2018/05/d39381/. Accessed 20 June, 2018
White JM, Palkin AS (2017) Religion and nationalism in modern Russia: or the uses and abuses of Edinoverie Sov Post Sov Rev 44(3):343-356

Ziegler CE (2016) Russia as a nationalizing state: Rejecting the western liberal order International Politics 53(5):555-573

\section{Additional information}

Competing interests: The authors declare no competing interests.

Reprints and permission information is available online at http://www.nature.com/ reprints

Publisher's note: Springer Nature remains neutral with regard to jurisdictional claims in published maps and institutional affiliations.

(c) (i) Open Access This article is licensed under a Creative Commons Attribution 4.0 International License, which permits use, sharing, adaptation, distribution and reproduction in any medium or format, as long as you give appropriate credit to the original author(s) and the source, provide a link to the Creative Commons license, and indicate if changes were made. The images or other third party material in this article are included in the article's Creative Commons license, unless indicated otherwise in a credit line to the material. If material is not included in the article's Creative Commons license and your intended use is not permitted by statutory regulation or exceeds the permitted use, you will need to obtain permission directly from the copyright holder. To view a copy of this license, visit http://creativecommons.org/ licenses/by/4.0/.

(c) The Author(s) 2018 